\title{
Gero Fuchs
}

\section{Gewinn als Umbruch der Ordnung?}

Der Fall des Siegburger Töpfers Peter Knütgen im 16. Jahrhundert

[Breaking the System with Profit? The Sixteenth Century Case of the Siegburg Potter Peter Knütgen.]

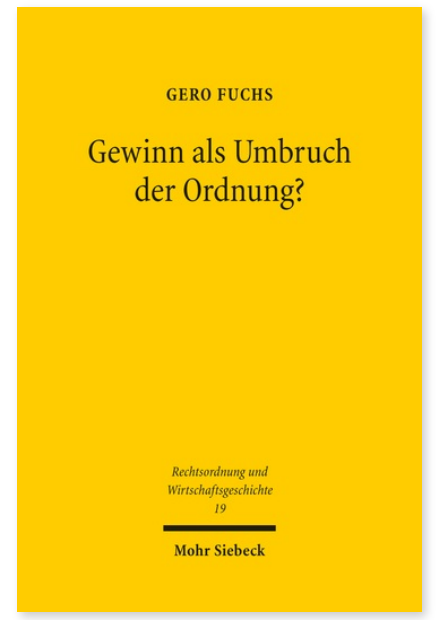

Published in German.

Why would an artisan be barred from selling his skillfully produced wares for a profit? The Siegburg potter Peter Knütgen faced just this scenario in 1560 when his guild accused him of bagging large profits to the detriment of common economic aims. Gero Fuchs explains why the powers-that-were felt it so important to nip the potter's business acumen in the bud.

2019. XV, 195 pages. ROWG 19

ISBN 978-3-16-156852-7

sewn paper 69,00€

ISBN 978-3-16-156853-4

eBook PDF $69,00 €$

Gero Fuchs Geboren 1987; Studium der Rechts- und Geschichtswissenschaft an der Universität Bonn; 2013 Erstes juristisches Staatsexamen; 2015 Bachelor of Arts; Wissenschaftlicher Mitarbeiter am Institut für Deutsche und Rheinische Rechtsgeschichte der Universität Bonn; Rechtsreferendariat am OLG Köln; 2018 Promotion und Zweites juristisches Staatsexamen; Akademischer Rat auf Zeit am Institut für Deutsche und Rheinische Rechtsgeschichte der Universität Bonn.

Order now:

https://www.mohrsiebeck.com/en/book/gewinn-als-umbruch-der-ordnung-9783161568527?no_cache=1 order@mohrsiebeck.com

Phone: +49 (0)7071-923-17

Fax: $+49(0) 7071-51104$ 